\title{
Fire hazard zonation of Bardia National Park, Nepal: A disaster preparedness approach
}

\author{
B Ghimire*, K Bhujel, K Rijal \\ Central Department of Environmental Science, Tribhuvan University, Kathmandu, Nepal
}

\begin{abstract}
This study was focused to prepare fire hazard map of Bardia National Park (BNP) through fire hazard zonation model. BNP is located at western Terai (lowland plains) of Nepal. The model was prepared by using four sub-models. The sub-models were prepared by considering nine parameters selected on the basis of their significance in fire risk assessments and their data availability. Remotely sensed data and Geographic Information System (GIS) were used during model preparation and validation process. The output map from the model was validated using Moderate Resolution Imaging Spectroradiometer (MODIS) active fire points (2001- May 2014) within BNP. Very high fire risk areas were identified along southern boundary; Northeast and Northwest part of the park covering about $5 \%$ of the park area. Similarly, about $31 \%$ of the park area was identified as high risk zone and $31.43 \%$ area of BNP was identified as medium risk zone. MODIS active fire data was very useful for validation process that showed proportionate result with the area coverage of predicted risk classes. The validation result suggests that this prepared model can be used to prepare fire hazard zonation maps and preparedness plans of areas similar to BNP. The plans to prevent and control wildfire in BNP should be focused on high risk areas through preparedness initiatives, awareness activities and capacity building of fire fighting team. Reducing surface fuel load and fuel continuity during pre-fire season (Dec-Feb) in general and particularly during February shall reduce fire occurrences and its damage to a great extent.
\end{abstract}

Key Words: Index Model, Remote Sensing and GIS, Risk, Wildfires

\section{Introduction}

Fire has been an integral ecological process since the arrival of vegetation on the landscape (Flannigan \& Wotton, 2001). If properly used, fire can be an ecological tool of great value (Odum \& Barrett, 2010) but wildfires become too destructive when uncontrolled (NHM, 2012). F ires are now a major threat to many forests and the biodiversity but surprisingly little attention has been paid to the impact of fires on forest ecosystems and biodiversity (CBD Secretariat, 2001). Wildfires release the sequestered carbon into the atmosphere as complex mixture of particles and greenhouse gases that potentially affect climate (Amiro et al., 2001). Annual carbon emission (total carbon including $\mathrm{CO}_{2}, \mathrm{CH}_{4}, \mathrm{CO}$ and black carbon) during 1997 to 2009 from tropical deforestation and degradation fires was estimated 1.39 Giga tons $\mathrm{CO}_{2} \mathrm{eq}$ which was $20 \%$ of all fire emissions (IPCC, 2014).

Two essential components of forest fire are the source of fire and the availability of fuel sources (Panda, 2005). Like in any land zoning process, unifor $m$ (homogenous) areas are defined within a ter ritory according to given criteria during fire hazard zonation (Bovio \& Camia, 1997). The

*Corresponding author, email address: ghimirebhrt@gmail.com diversity of factors that affect beginning and spreading of forest fires dictates the use of an integrated analysis approach (Chuvieco \& Congalton, 1989).

Forest fire is considered as a problem in forest management system in Nepal (Sharma, 2006). Forest area burnt annually (during March-June) in Nepal is in the order of more than 400,000 hectare causing destr uction and degradation of forest and biodiversity (Bajrachar ya, 2002). The national institutional capacity to combat the wildfires is ver y weak and there is no systematic and complete record of occurrences of forest fires and their impacts (GoN/MFS C, 2002). Recently International Centre for Integrated Mountain Development (ICIMOD) in close collaboration with the Department of Forest (DoF), Nepal has developed forest fire detection and monitoring system for Nepal based on Moderate Resolution Imaging Spectroradiometer (MODIS) with the support of United States Agency for International Development (USAID) and National Aeronautics and Space Administration (NASA) (ICIMOD, 2012). 
For emergency preparedness and effective response, fire risk assessments prior to the disaster events can be one of the effective mitigation measures especially to minimize the possible loss and damages caused by wildfires. Countries like Australia, USA and Canada are using fire hazard maps for effective preparedness activities to combat wildfires, but Nepal lacks these kinds of practices. Sharma (2006) has also recognized the need of preparation and dissemination of fire hazard maps as one of the disaster preparedness activities in Nepal. So, the present study was undertaken as an initiative towards this, with the main objective to prepare fire hazard zonation map of Bardia National Park, Nepal. Identification of high risk areas will help park management authorities to prepare effective plan for prevention and control of wildfires.

\section{Materials and Methods \\ Study Area}

Bardia National Park (BNP) of Nepal, which is the lar gest National Park $\left(968 \mathrm{~km}^{2}\right.$ ) of Terai region (F ig. 1). It was established (status of a National Park in 1988) to protect representative ecosystems and habitats of endangered species. About $70 \%$ of the forest consists of Sal ( Shorea robusta) trees with a mixture of grassland and riverine forests (DNPWC, 2013). The elevation ranges from $134 \mathrm{~m}$ to $1573 \mathrm{~m}$ having tropical and subtropical climate and the monsoon rain starts from June and lasts until September.

\section{Methods}

A fire hazard zonation model was built using GIS. The model was raster based, static index model. An index model calculates the index value for each unit area and produces a ranked map based on the index values while static models deal with spatial data at a given time (Chang, 2008). The fire hazard zonation model was the combination of four sub models.
The fire regime at any location is the result of complex interactions among fuel, topography, ignitions and weather (Flannigan et al., 2000). Thus, the sub-models used were fuel risk sub model, proximity risk sub-model, topographical risk sub model and meteorological risk sub-model. T otal nine parameters were used to build those sub models and the parameters of each sub model were selected based on their significance in fire risk assessments and data availability (Fig. 2).

Raster map (30 m x 30 m) of each parameter was classified into five classes and index value of 1 (low) to 5 (high) was assigned to each class based on their characteristics towards fire risk (Table 1). The sub-models were then prepared by weighted linear combination of the parameters. Similarly, fire hazard zonation model was prepared by weighted linear combination of the sub-models.

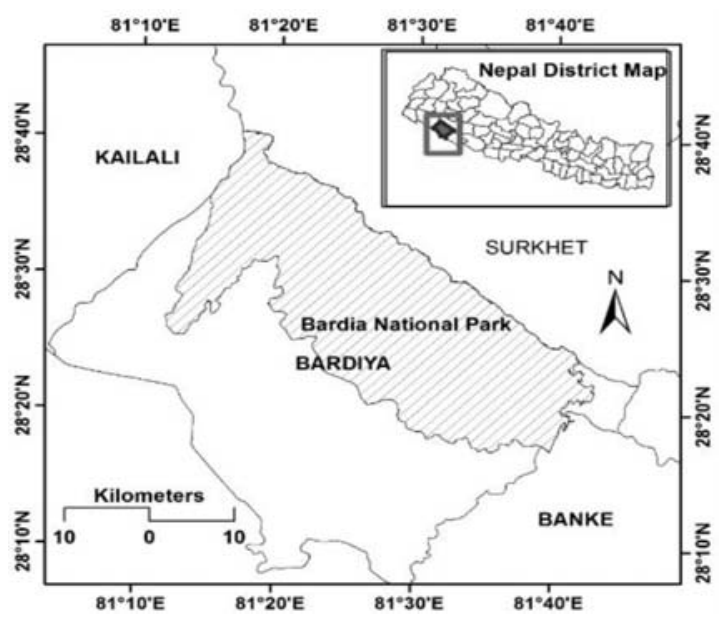

Fig. 1 Location of Bardia National Park

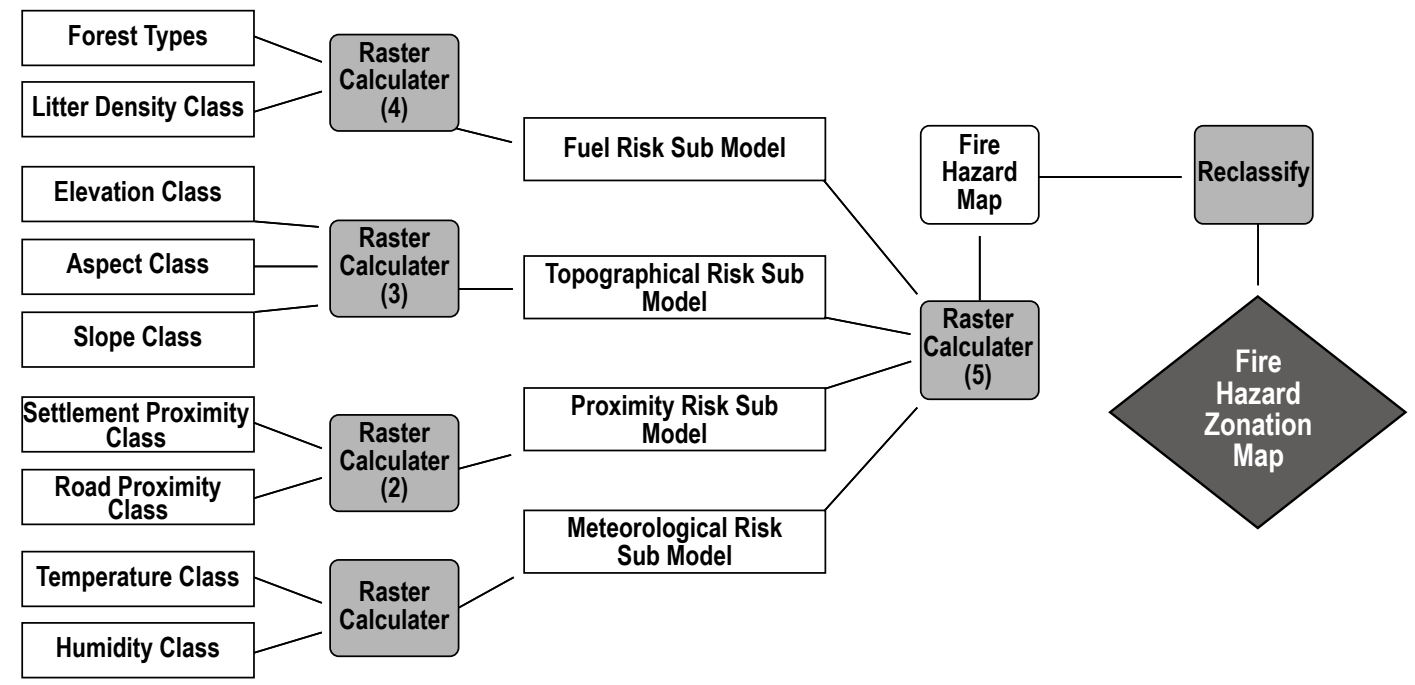

Fig. 2 Layout of Fire Hazard Zonation Model 


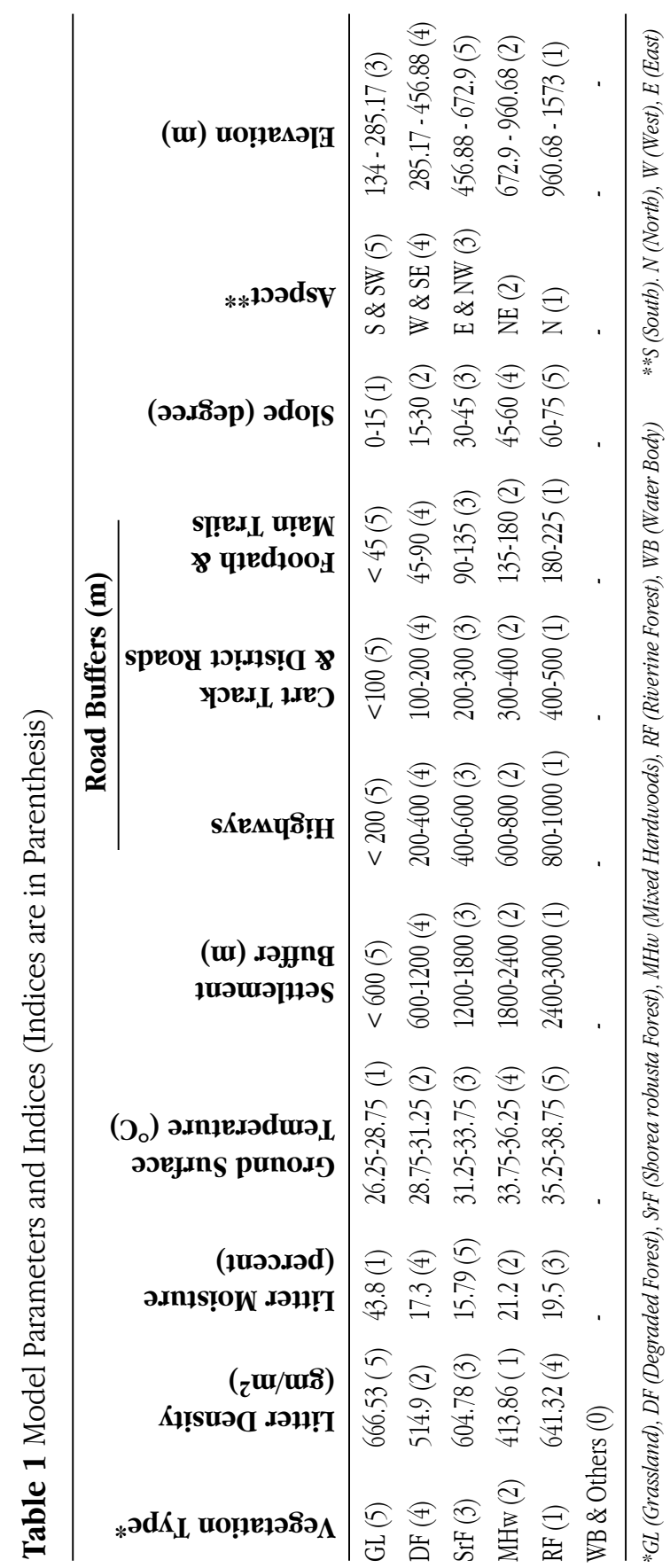

Vegetation type map of Bardia National Park was prepared from satellite imager y (LANDSAT 8) of April, 2013. The ground litter density and litter moisture content was calculated by field measurement during March and April, 2014. F ive classes of buffer distances were classified by equal inter val classification of road networks and settlements maps obtained from digital topographic maps prepared by Sur vey Department of Nepal. The slope, aspect and elevation maps were prepared from Digital Elevation Model (DEM) using ArcMap 10.1 from the data obtained from digital topographic maps. Average land surface temperature distribution data was obtained from MODIS (MOD11A1 from Terra satellite) in gridded format (1 km x $1 \mathrm{~km}$ grids) of April, 2014. Moisture content of litter was used as a proxy indicator for relative humidity to prepare humidity map. Raster based fire hazard zonation map having five risk classes was prepared using outputs of four sub-models. The model was validated by comparing the obtained results with actual past fire occurrences (2001 to May 2014) within BNP as recorded by MODIS satellites. Equations 1, 2, 3, 4 and 5 were calculated by Analytic Hierarchy Process (AHP) using pair wise comparison scales (Saaty, 1990, 2008) which were used to obtain the respective maps.

Equation 1. Fuel Risk Map = Forest Types X $0.75+$ Litter Density X 0.25

Equation 2. Proximity Risk Map $=$ Settlement Proximity Risk X 0.67 + Road Proximity Risk X 0.33

Equation 3. Topographical Risk Map $=$ Elevation Risk X 0.12 + Slope Risk X 0.65+ Aspect Risk X 0.23

Equation 4. Meteorological Risk Map $=$ Temperature Risk X 0.88 + Humidity Risk X 0.12

Equation 5. Fire Hazard Zonation Map = Fuel Risk X 0.64 + Proximity Risk X $0.19+$ Meteorological Risk X $0.10+$ Topographical Risk X 0.07

Results

\section{Status of Fire Ignition Points}

Total 1747 fire ignition points within BNP were recorded by MODIS satellites from 2001 to May 2014. Out of total detections, about $80 \%$ fires were detected with more than 50\% confidence. During this period, 2012 was the year receiving most fire incidents followed by 2003 and 2009. More annual fire events were recorded after 2008 than the previous years. Highest number of fire incidences was observed in the month of April (Fig. 3). 


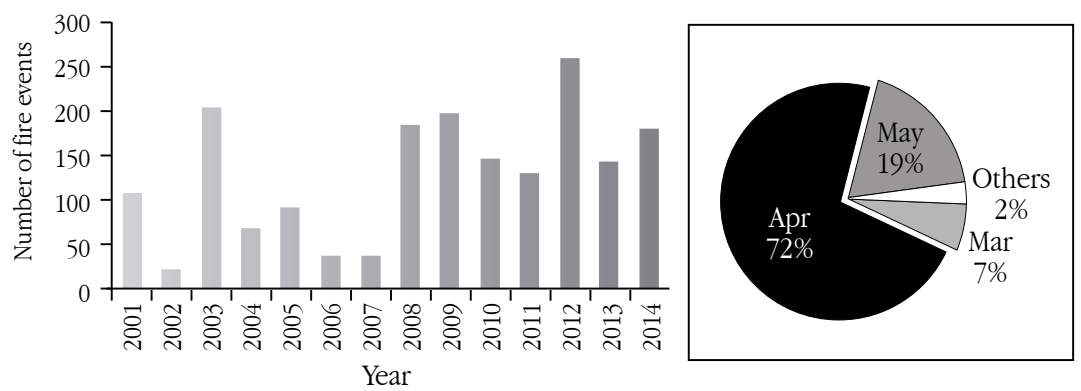

Fig. 3 Fire events in BNP, (a) Annual and (b) Monthly (2001-May 2014)

\section{Risk Maps}

Most of the ground surface of BNP was observed south and west facing. The elevation of BNP area was found stretched between $134 \mathrm{~m}$ and $1573 \mathrm{~m}$. About 44\% of the park area has elevation less than $285 \mathrm{~m}$. The slope within BNP ranges from $0-75$ degree. More than half of the ground surface have 0 15 degree slope (Fig. 4).

The vegetation of BNP is mainly dominated by Sal forest either in the form of pure Sal or as a component of mixed hardwoods. The pure Sal forest shares $44.97 \%$ area followed by mixed hardwoods (26.3\%). The litter density and moisture content of litter within different vegetation types are shown in Table 1. The fuel risk map obtained from the fuel risk submodel is shown in Fig. 5.

The proximity risk map obtained from proximity risk submodel showed about 52\% area of Bardia National Park is within $3 \mathrm{~km}$ distance from the nearby settlements and 6.42\% of the park area is within $600 \mathrm{~m}$ distance from the settlement areas. About 25\% area of the Bardia National Park is within $1 \mathrm{~km}$ distance from any kind of roads present within and around the park (Fig. 6).

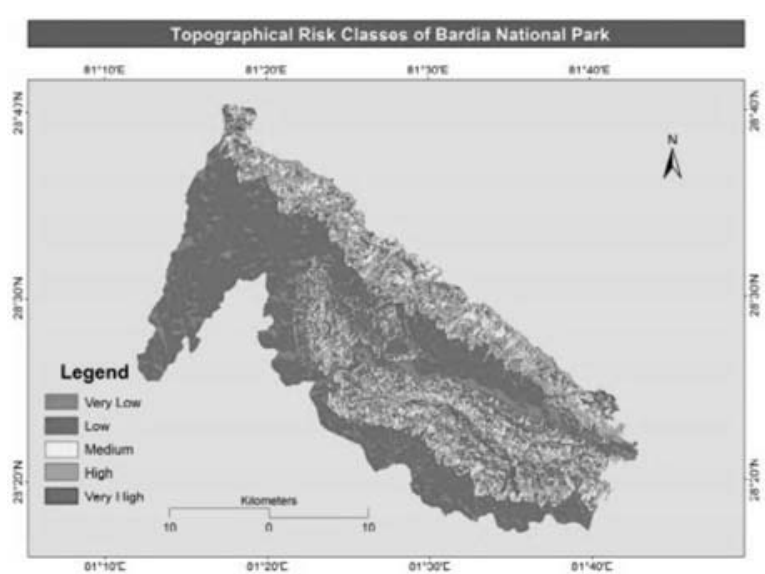

Fig. 4 Topographical Risk Map of BNP
The meteorological risk map shows average daytime temperature within BNP area of April 2014 was between $26.38{ }^{\circ} \mathrm{C}-38.62{ }^{\circ} \mathrm{C}$ from the MODIS gridded data (Fig. 7).

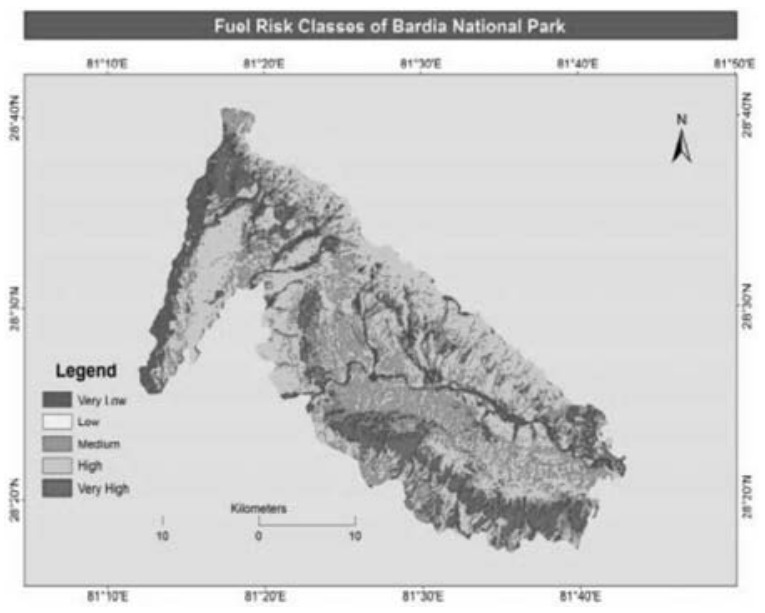

Fig. 5 Fuel Risk Map of BNP

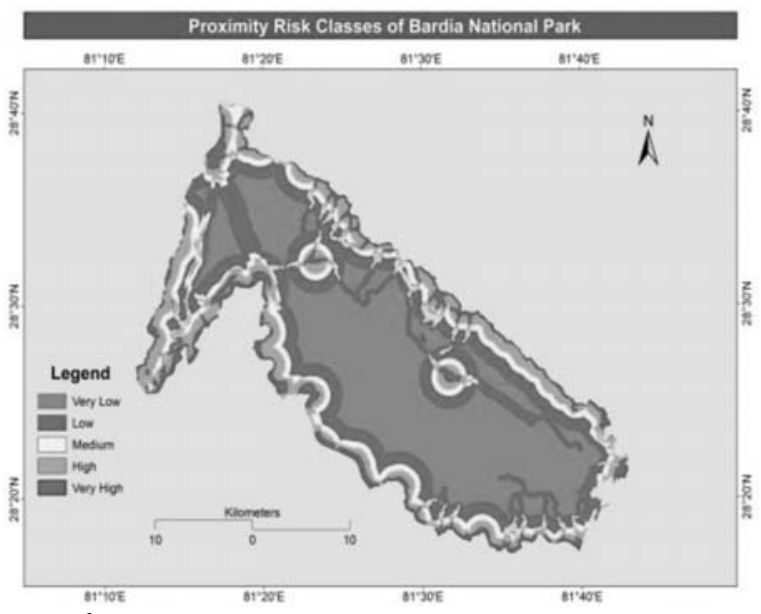

Fig. 6 Proximity Risk Map of BNP 


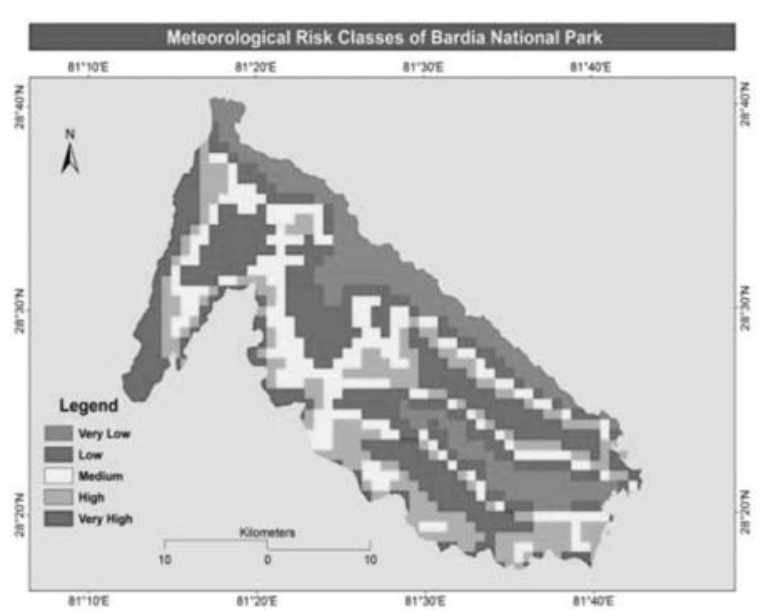

Fig. 7 Meteorological Risk Map of BNP

The fire hazard zonation map obtained by using four submodels' output shows very high risk areas along the southem boundary of BNP and in Northeast and Northwest part of the park, covering about $5 \%$ of the park area, while about $31 \%$ of the park area was identified as high risk zone (Fig. 8).

\section{Model Validation}

As a result of model validation process $\mathrm{F}$ ig. 9 shows the comparison between percentage area covered by model predicted risk classes and percentage of past fire ignition points within the area of each predicted risk class. Proportionate result has been obser ved during the comparison.

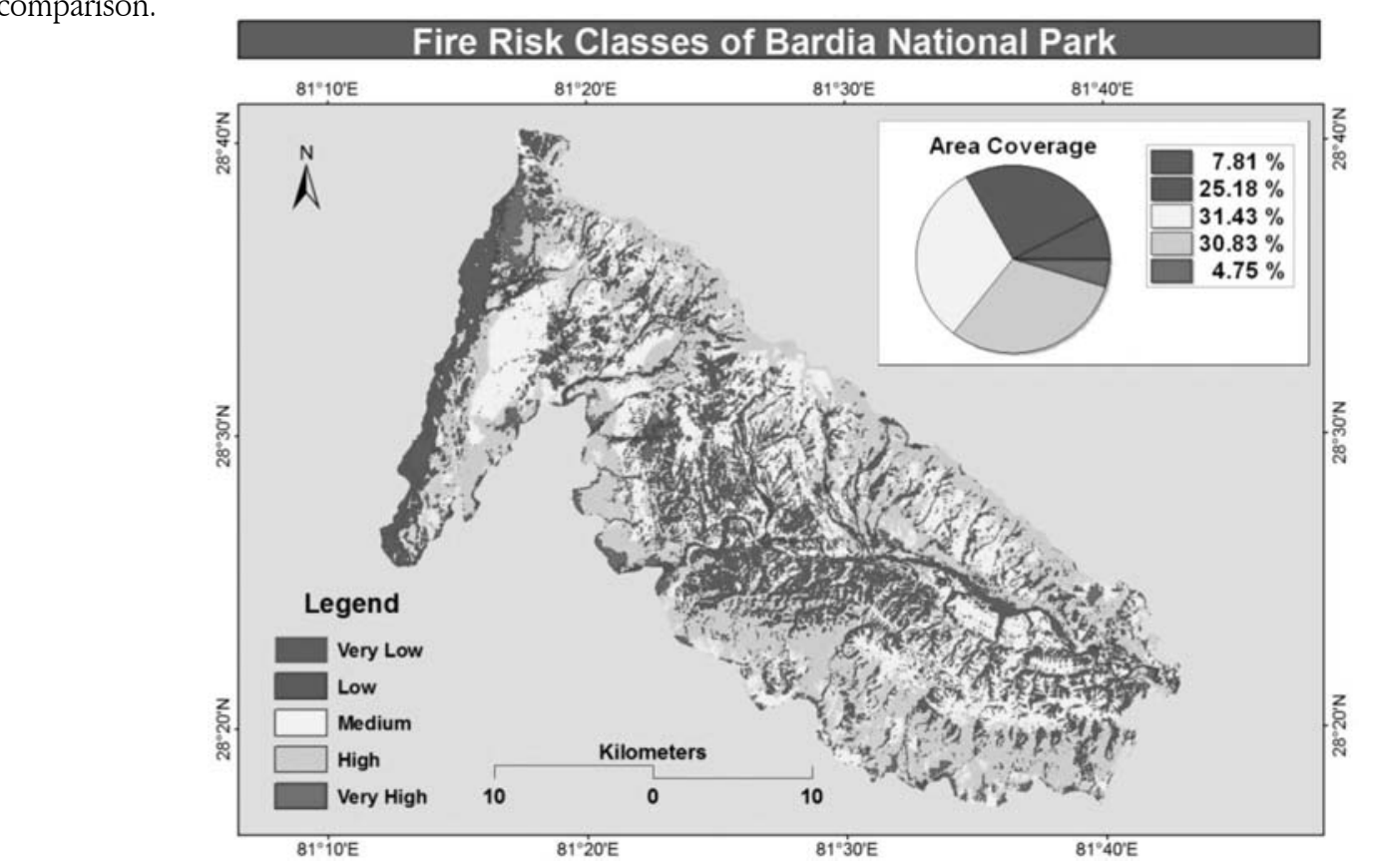

Fig. 8 Fire Hazard Zonation Map of BNP

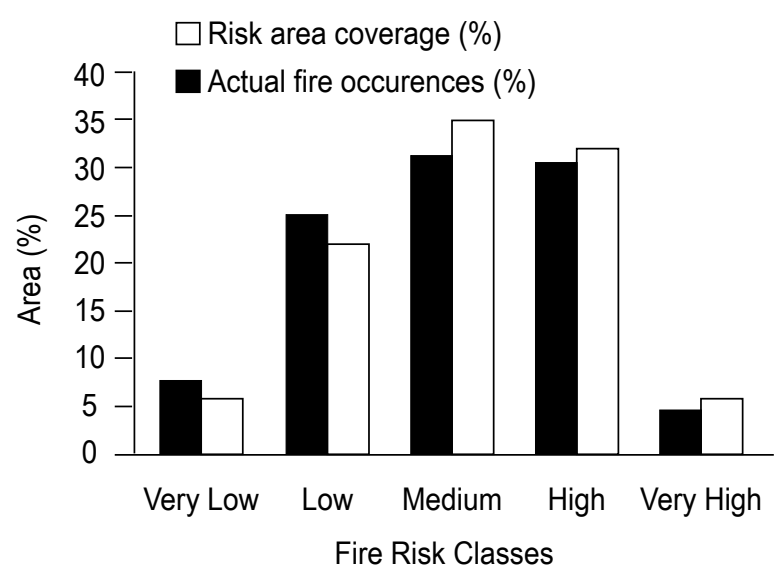

Fig. 9 Comparison of Risk Area Coverage and Actual Past Fire Occurrences

\section{Discussion}

The tropical and sub tropical climate of Bardia National Park is favorable for wildfire events during the fire months. MODIS active fire data shows most fire events during April followed by May (during 2001-May 2014) which is consistent with previous studies (Bajracharya, 2002; Bhatta, 2014; GoN/MFSC, 2002). Within the park area more fire events have been recorded in recent years (after 2008) than they were recorded before which may be attributed to changing climatic conditions due to anthropogenic causes. Bhatta (2014) has also observed increasing trend of fire events from 2001 to 2013 in Chitwan district of Nepal. 
The size and topography of BNP has added challenge for integrated fire management. Most of the fires occur red in Siwaliks and inner areas of park remain uncontrolled due to lack of resources. Except natural bar riers, only few fire breaks have been constructed in the park area where almost all of the fires are sur face fires. The National Park allows buffer zone residents to collect grasses and leaf litters for 35 days a year. This has helped to reduce ground litter density and fuel continuity. It is recommended to continue the practice every year, during February to reduce fire disasters within the park.

Analytic Hierarchy Process was used for calculating weights during ranking of various parameters and sub models. Although AHP is very easy technique for ranking and weight derivation, few drawbacks of this process has been criticized by various researchers. During weight derivation by this process possible results created by interaction of those parameters may be ignored due to its compensational behavior (Mahdevi et al., 2012). Hopkins (1977) also mentioned that weighted linear combination cannot deal with interdependence between factors.

The satellite image (LandSAT 8) was used to classif y the vegetation types of Bardia National Park. About $45 \%$ of the park area was obtained as pure Sal forest, while about 26\% and $15 \%$ of the park area was obtained as mixed hardwoods and degraded forests respectively. Comparing with the reference vegetation class map (WWF Nepal, 2005), slight deviation in areas of Sal forest and mixed hardwoods were obtained during the study, but results are comparable.

Highest litter density was obser ved in grasslands (666.53 $\left.\mathrm{gm} / \mathrm{m}^{2}\right)$ followed by riverine forest $\left(641.32 \mathrm{gm} / \mathrm{m}^{2}\right)$ while lowest litter density was obser ved in mixed hardwoods (413.86 gm/ $\mathrm{m}^{2}$ ). Rawat (2003) also mentioned that grasslands have maximum amount of inflammable material. In BNP, Giri (1997) found highest litter density in riverine forests (excluding grassland areas). Also the moisture content from litters of grasslands were found highest among others (43.8\%) which is due to the water content in clipped green grasses.

Based on geographical structure of BNP, about 70\% area was found below $500 \mathrm{~m}$ elevation and more than half of the area was observed having slope less than 15 degree. Slope has direct influence in fire spreading. According to Catchpole (2002), McArthur forest meter predicted that fire spread rate will double with 10 degree increase in slope. Also in areas having greater slope fire fighting becomes extremely difficult. Higher percentage of the slopes within BNP were found south facing than north facing ones thus increasing risk to wildfires. Sibanda (2011) observed more fire events in southern aspects while more past fire events were reported by Rathaur (2006) in middle elevations (600 m-800 m).
Being a protected area, no other settlements are present within the park area except few security posts of Nepal Amy. But, few people from settlements along southern boundary invade into the park in search of non-timber forest products (NTFPs), grass and firewood which has greatly increased the risk of ignition. Uriarte et al.(2012) mentioned that proximity to roads increase fire frequency. Available road networks within the park include highways, district roads, cart tracks and trails. Activities of passers-by in those roads increase the probability of ignition.

Based on validation results, about $28 \%$ of the fire incidences were observed on areas having low and very low risk areas. So, there is still need of increasing prediction accuracy of the model. The accuracy can be increased by adding other important parameters to the model which influences fire regime. Santiago and Kheladze (2011) modified their first model by adding agriculture practice information and then accuracy of the modified model increased greatly. Most of the wildfire influencing parameters varies greatly in temporal scales (throughout the year and also during fire seasons). So, dynamic models can enhance the model's predictive capacity.

\section{Conclusion}

A fire hazard zonation map (raster based) having five risk classes of Bardia National Park was prepared by using fire hazard zonation model. Remote Sensing and GIS techniques provided the system to prepare the hazard map at a landscape scale.

The $5 \%$ area of BNP was identified as very high fire risk area located along the souther $n$ boundary, Northeast and Northwest part of the park. Similarly, about 31\% and 32\% of the park area were identified as high and medium fire risk zones respectively. MODIS active fire data was ver y helpful for validation which showed proportionate result with the area coverage of predicted risk classes. Data unavailability of some meteorological parameters and less resource availability limited the use of other important wildfire affecting parameters.

The validation result shows that this model can be used to prepare fire hazard zonation map of similar areas. Similarly, the fire hazard zonation map can be used to prepare and restructure the plan towards prevention and control of wildfire disasters in high fire risk areas.

\section{Acknowledgements}

The authors are very much grateful to Central Department of Environmental Science (CDES), Tribhuvan University and particularly grateful to Strengthening Disaster Risk Management in Academia (SDRMA) project (United Nations Development Programme - CDES collaboration) for providing

\section{解TU-CDES}


support grant to conduct this research work. The authors are thankful to all the staffs of Bardia National Park, Bardia Conservation Program. The authors offer special thanks to field guides Anuram Chaudhary, Binay Chaudhary and Prakash Chaudhary for their generous cooperation.

\section{References}

Amiro, B.D., Todd, J.B., Wotton, B.M., Logan, K.A., Flannigan, M.D., Stocks, B.J., Mason, J.A., Martell D.L. and Hirsch, K.G. (2001). Direct carbon emissions from Canadian forest fires, 1959-1999. Canadian Journal of Forest Research, 31, 512-525.

Bajracharya, K. M. (2002). Forest Fire Situation in Nepal. International Forest Fire News, 26, 84-86.

Bhatta, M. (2014). Forest fire risk in Chitwan by using Remote Sensing and GIS. M.Sc. dissertation submitted to Central Department of Environmental Sciences, Tribhuvan University.

Bovio, G. and Camia, A. (1997). Land Zoning Based on Fire History. International Journal of Wildland Fire, 7, 249258.

Catchpole, W. (2002). Fire Properties and burn patterns in Heterogeneous Landscapes. In R.A. Bradstock, J.E. Williams and A.M. Gill (Eds.) Flammable Australia: The fire Regimes and Biodiversity of a Continent. Cambridge University Press.

CBD Secretariat, (2001). Impacts of human-caused fires on biodiversity and ecosystem functioning, and their causes in tropical, temperate and boreal forest biomes. Convention on Biological Diversity secretariat. Montreal.

Chang, K. T. (2008). Introduction to Geographic Information System. Fourth edition. Tata MC Graw Hill, New Delhi.

Chuvieco, E. and Congalton, R.G. (1989). Application of Remote Sensing and Geographic Information Systems to Forest Fire Hazard Mapping. Remote Sensing of Environment, 29, 147-159.

DNPWC, (2013). Protected Area Information. Available online at: (accessed on 8 July 2013). Department of National Parks and Wildlife Conservation, Nepal.

Flannigan M.D., Stocks B.J., and Wotton B.M. (2000). Climate Change and Forest Fires. The Science of the Total Environment 262, Elsevier.

Flannigan, M.D. and Wotton, B.M. (2001). Climate, Weather and Area Burned. In K. Miyanishi, \& E. Johnson (Eds.) Forest Fires: Behavior and Ecological Effects. Academic Press.

Giri, A. (1997). Aboveground biomass of trees and litter production in the Royal Bardia National Park, Nepal. M.Sc. dissertation submitted to Central Department of Botany, Tribhuvan University.

GoN/MFSC, (2002). Nepal Biodiversity Strategy. Ministry of Forests and Soil Conservation, His Majesty's Government of Nepal.
Hopkins, L. D. (1977). Methods for generating land suitability maps: a comparative evaluation. Journal of the American institute of planners, 43, 386-400

ICIMOD, (2012). Forest Fire Detection and Monitoring System in Nepal. Brochure. International Centre for Integrated Mountain Development, Kathmandu, Nepal.

IPCC, (2014). Climate Change 2014: Mitigation of Climate Change. Contribution of Working Group III to the Fifth Assessment Report of the Intergovernmental Panel on Climate Change.

Mahdavi, A., FallahShamsi, S.R. and Nazari, R. (2012). Forest and Rangelands' wildfire risk zoning using GIS and AHP techniques. Caspian Journal of Environmental Sciences, $10,43-52$.

NHM, (2012). Forest Fires. Available online at: (accessed on 7 August 2014). Natural History Museum, London.

Odum, E.P. and Barrett, G.W. (2010). Fundamentals of Ecology. Fifth edition. Cengage Learning, New Delhi.

Panda, B. C. (2005). Remote sensing principles and applications. VIVA Books, New Delhi.

Rathaur, S. (2006). Fire Risk Assessment for Tiger Prey-base in Chilla Range and vicinity, Rajaji National Park using Remote Sensing and GIS. M. Sc. thesis submitted to the International Institute for Geo-information Science and Earth Observation.

Rawat, G.S. (2003). Fire risk assessment for forest fire control management in Chilla forest range of Rajaji National Park, Uttaranchal (India). M.Sc. Geoinformatics dissertation. Indian Institute of Remote Sensing, Dehradun.

Saaty, T.L. (1990). How to make a decision: The Analytic Hierarchy Process. European Journal of Operational Research, 48, 9-26.

Saaty, T.L. (2008). Decision making with the analytic hierarchy process. International Journal of Services Sciences, Vol.1.

Santiago, I.T.F. and Kheladze, N. (2011). GIS wildland fire bazard modeling in Georgia. MATRA Project report. Caucasus Environmental NGO Network.

Sharma, S. P. (2006). Participatory Forest Fire Management: an Approach. International Forest Fire News, 34, 35-45.

Sibanda, C. (2011). Modelling Forest Fire Behavior and Carbon Emission in the Ludhikbola Watershed, Gorkha District, Nepal. M. Sc. thesis submitted to the Faculty of Geo-Information Science and Earth Observation of the University of Twente.

Uriarte, M., Vasquez, M.P., De Fries, R.S., Fernandes, K., Velez, V.G., Walter, E. Baethgen, W.E., and Padoch, C. (2012). Depopulation of rural landscapes exacerbates fire activity in the western Amazon. Proceedings of the National Academy of Sciences of the United States of America, Vol. 109.

WWF Nepal, (2005). Bardia National Park Classified Landsat TM Image 2001. Available online at: (accessed on 27 March 2013). World Wide Fund for Nature, Nepal. 